\title{
Effects of Anaemia Parameters on Metabolic Control in Children with Type-1 Diabetes Mellitus
}

\author{
Tip-1 Diabetes Mellituslu Çocuklarda Anemi Parametrelerinin Metabolik Kontrol \\ Üzerine Etkisi
}

\author{
(1) Senem Ayça, (1) Nilgün Selçuk Duru, (1) Murat Elevli \\ University of Health Sciences Turkey, Haseki Training and Research Hospital, Clinic of Pediatrics, İstanbul, Turkey
}

\begin{abstract}
Introduction: Anaemia parameters in children with type1 diabetes and their relationship with metabolic control has received little attention in the literature. We aimed to determine the incidence of anaemia and to investigate anaemia parameters and their relationship with metabolic control in paediatric type-1 diabetes mellitus (DM) patients.

Methods: A retrospective case control study was conducted using the medical records of 33 patients with type- 1 diabetes and 33 healthy children. In both groups, anaemia parameters including haemogram parameters and iron, total iron-binding capacity (TIBC), ferritin, vitamin B12 and folate were noted. In the case group, $\mathrm{HbA} 1 \mathrm{C}$ levels, duration of diabetes and insulin treatment dose were also noted.
\end{abstract}

Results: Mean diabetes duration was $8.4 \pm 11.4$ months, mean HbA1c level was $10.6 \pm 2.9$ and mean insulin treatment dose was $0.7 \pm 0.2 \mathrm{u} / \mathrm{kg} /$ day. Comparison of haemogram parameters between the case and control groups were non-significant. TIBC was lower in the patients than in controls. Folate and ferritin were higher in patients than in controls.

Conclusion: According to this study, type-1 DM did not increase the risk for anaemia in children. Ferritin was higher in patients than in controls, which suggests that inflammation was present in the patients with type-1 DM.

Keywords: Anaemia, type-1, diabetes mellitus, HbA1c, insulin, children

\section{öZ}

Amaç: Tip-1 diyabetli çocuklarda anemi parametrelerinin metabolik kontrolle ilișkisi literatürde az yer almaktadır. Tip1 diabetes mellitus (DM) tanılı çocuklarda anemi insidansı, anemi parametreleri ve bu parametrelerin metabolik kontrolle ilişkisinin araştırılması planlanmıştır.

Yöntemler: Benzer yaş ve cinsiyette olan 33 tip-1 diyabetli ve 33 sağlıklı çocuğun tıbbi kayıtlarından retrospektif olgu kontrol çalışması yapılmıştır. Her iki grupta hemogram parametreleri ve demir, total demir bağlama kapasitesi (TDBK), ferritin, vitamin B12, folat anemi parametreleri olarak kayıt edildi. Ayrıca olgu grubunda HbA1c seviyeleri, diyabet süresi ve insülin tedavi dozu not edildi.

Bulgular: Tip-1 DM'li çocuklarda diyabet süresi $8,4 \pm 11,4$ ay, HbA1c seviyesi $10,6 \pm 2,9$ ve insülin tedavi dozu $0,7 \pm 0,2 \mathrm{u} / \mathrm{kg} /$ gündü. Olgu ve kontrol grubunda hemogram parametrelerinin karşılaştırılmasında anlamlı fark saptanmadı. TDBK kontrol grubuna göre daha düşük saptandı $(p=0,02)$. Folat ve ferritin seviyesi hastalarda kontrol grubuna göre daha yüksek saptandı $(p=0,001)$.

Sonuç: Bu çalıșmaya göre tip-1 DM çocuklarda anemi riskini artırmamaktadır. Hastalarda ferritin seviyesi kontrole göre daha yüksek saptanmıștır, bu durum tip-1 DM'de enflamasyonun varlığını desteklemektedir.

Anahtar Kelimeler: Anemi, tip-1, diabetes mellitus, HbA1c, insülin, çocuk

\section{Introduction}

Type- 1 diabetes mellitus (DM) is one of the most common chronic childhood diseases and its incidence has doubled during the last decade. In some studies, due to the chronic inflammatory state of type-1 DM, it was considered that children may be at a higher risk of developing anaemia, which may contribute to disease complications (1,2). Anaemia in type-1 DM may have a multifactorial background; specifically, it may be associated a more rapid erythrocyte turnover leading to higher HbA1c
(3). Other autoimmune diseases (thyroiditis, celiac disease, Addison's disease and atrophic gastritis) may be accompanied by type 1 DM and can lead to anaemia. Some studies showed that the most common causes of anaemia in children with type-1 DM is iron deficiency $(4,5)$. Iron deficiency in adults with type-1 DM is associated with prolonged illness and kidney malfunction $(6,7)$.

In the present study, we aimed to assess the haemogram and iron metabolism parameters, as well as vitamin B12 and folate levels in
Address for Correspondence/Yazıșma Adresi: Senem Ayça MD, University of Health Sciences Turkey, Haseki Training and Research Hospital, Clinic of Pediatrics, İstanbul, Turkey

Phone: +90 5557086323 E-mail: senemkaleci85@gmail.com ORCID ID: orcid.org/0000-0001-7486-9655

Cite this article as/Atıf: Ayça S, Selçuk Duru N, Elevli M. Effects of Anaemia Parameters on Metabolic Control in Children with Type-1 Diabetes Mellitus. İstanbul Med J 2020; 21(5): 397-400.

(c) Copyright 2020 by the University of Health Sciences Turkey, Istanbul Training and Research Hospital/Istanbul Medical Journal published by Galenos Publishing House.

(C) Telif Hakkı 2020 Sağlık Bilimleri Üniversitesi istanbul Ĕgitim ve Araştırma Hastanesi/Istanbul Tıp Dergisi, Galenos Yayınevi tarafından basılmıștır.

Received/Geliș Tarihi: 06.06.2020 Accepted/Kabul Tarihi: 04.08.2020 
children with type-1 DM. These results were then compared with those obtained from a group of healthy children to estimate the relation between type-1 DM and metabolic factors such as disease duration, insulin treatment dose and $\mathrm{HbA1c}$ levels.

\section{Methods}

\section{Subjects}

This study was a case control study at the paediatric clinic of Haseki Training and Research Hospital. A total of 66 children were recruited into the study: 33 with type-1 DM and 33 healthy children as a control group. Blood samples were collected during the routine control visit in the outpatient clinic. The patients were diagnosed according to the criteria established by the American Diabetes Association (8). Exclusion criteria were as follows: other autoimmune diseases (celiac, thyroiditis), abnormal renal/hepatic biochemical values, macrovascular complications and infections. Patients with haemoglobinopathies were also excluded from the study. Children enrolled for this study, according to their medical records, did not have chronic diabetes complications. The control group consisted of healthy children having similar characteristics with the patient group in terms of gender and age. They had visited the clinic for routine medical examination and were not diagnosed with any kind of disease. None of the participants had a history of iron supplementation or blood transfusion in the last six months.

In both groups, haemogram parameters including red blood cells, haemoglobin (HGB), haematocrit, mean corpuscular volume, mean corpuscular HGB and anaemia parameters including iron, iron-binding capacity, ferritin, vitamin B12 and folate were noted. In the case group, $\mathrm{HbA} 1 \mathrm{c}$ levels, duration of diabetes and insulin subcutaneous treatment dose (insulin $/ \mathrm{kg} / \mathrm{day}$ ) were noted. The reference ranges were as follows: $\mathrm{HGB}<12 \mathrm{gr} / \mathrm{dL}$ for the diagnosis of anaemia and red cell distribution width $(\mathrm{RDW})>14$, serum iron $<30 \mu \mathrm{g} / \mathrm{dL}$, total serum iron-binding capacity $>350 \mu \mathrm{g} / \mathrm{dL}$ and ferritin $<16 \mathrm{ng} / \mathrm{mL}$ for the diagnosis of iron deficiency anaemia.

\section{Ethics Statement}

Informed consent forms were completed by all the participants. The study protocol was approved by the Ethics Committee of Haseki Training and Research Hospital (protocol number: 79-02/05/2014) and the study was performed in accordance with the Declaration of Helsinki.

\section{Biochemical Analysis}

Blood samples were collected (without stasis after morning fasting) from all the participants. Serum samples placed into tubes with gel were allowed to clot before centrifugation. Following centrifugation for 10 $\min$ at $1000 \mathrm{~g}$, the serum was aliquoted and kept at $-70^{\circ} \mathrm{C}$ until the day of the study.

The samples for haemogram were moved into tubes containing K2EDTA (Becton Dickinson, UK) and the analysis was performed using an LH 780 (Beckman Coulter, USA) fully automated haematology system. HbA1c was measured using a turbidimetric inhibition immunoassay with VARIANT II autoanalyser, for which 4.8\%-6\% were within normal ranges and higher levels were considered significant. Serum iron levels and total ironbinding capacity (TIBC) were measured using the calorimetric method and a Cobas Integra 800 analyzer Roche, Mannheim, Germany). Ferritin, folate and vitamin B12 levels were determined via chemiluminescence immunoassays and an autoanalyser (Elecsys E170, Japan).

\section{Statistical Analysis}

SPSS version 15.0 was used for data analysis. For the comparison of the two groups, Student's t-test was used when the numerical variables were in the normal ranges and Mann-Whitney $U$ test was used for those in abnormal ranges. Categorical variable ratios between the groups were analysed with the chi-square test. Correlations between the numerical variables were assessed by Spearman's correlation analysis. A p-value of $<0.05$ was considered statistically significant.

\section{Results}

Among the 33 children in the case group, 18 were males (54.5\%) and 15 were females (45.5\%); in the control group, 18 children were males (54.5\%) and 15 were females (45.5\%). The mean age of the case group was $12.5 \pm 3.8$ years and that of the control group was $12.3 \pm 2.6$ years. There was no statistically significant difference between the groups in terms of age or gender. In the case group, the duration of diabetes was 0-42 months (8.4 \pm 11.4 months), HbA1c levels were 10.6 \pm 2.9 and insulin treatment doses were $0.7 \pm 0.2 \mathrm{u} / \mathrm{kg} /$ day (Table 1 ).

Comparison of the haemogram parameters of the patient and control groups were non-significant, but both ferritin and folate concentrations increased significantly in the case group $(p=0.001)$ and the TIBC was significantly decreased ( $p=0.022$ ) (Table 2). Comparison of the laboratory parameters in type-1 DM patients according to the duration of DM was not significant between $\leq 12$ months and $>12$ months.

According to the HGB levels, the case group was divided into two groups: $>12 \mathrm{gr} / \mathrm{dL}$ and $<12 \mathrm{gr} / \mathrm{dL}$. There was no significant between these groups in terms of age, gender, duration of diabetes, $\mathrm{HbA} 1 \mathrm{C}$ and insulin treatment dose.

In the case group, correlations of haemogram and anaemia parameters with duration of diabetes were not significant. In addition, correlations of insulin treatment dose with haemogram-anaemia parameters were not significant. Correlations of $\mathrm{HbA} 1 \mathrm{C}$ and anaemia-haemogram parameters were not significant, but there was a significant negative correlation of serum folate concentration with $\mathrm{HbA1c}$ (Table 3).

Table 1. The demographic features and clinical findings of the patients with type-1 DM and healthy control

\begin{tabular}{|l|l|l|l|}
\hline Parameters & $\begin{array}{l}\text { DM type-1 } \\
(\mathbf{n = 3 3 )}\end{array}$ & $\begin{array}{l}\text { Controls } \\
(\mathbf{n = 3 3 )}\end{array}$ & $\mathbf{p}$ \\
\hline Age (years) & $12.5 \pm 3.8(4-18)$ & $12.3 \pm 2.6(7-17)$ & 0.597 \\
\hline Gender (females, \%) & $15(45.5)$ & $15(45.5)$ & 1.000 \\
\hline $\begin{array}{l}\text { Duration of diabetes } \\
\text { (month) }\end{array}$ & $8.4 \pm 11.4(0-42)$ & - & - \\
\hline Insulin (U/kg/day) & $0.7 \pm 0.2(0.4-1.3)$ & - & - \\
\hline HbA1c (\%) & $10.6 \pm 2.9(6.5-18.6)$ & - & - \\
\hline DM: Diabetes mellitus & & & \\
\hline
\end{tabular}


Table 2. Comparison of laboratory parameters between the patients and controls

\begin{tabular}{|l|l|l|l|}
\hline Parameters & DM type-1 $(\mathbf{n}=\mathbf{3 3})$ & Controls $(\mathbf{n}=33)$ & $\mathbf{p}$ \\
\hline Haemoglobin $(\mathrm{g} / \mathrm{dL})$ & $13.3 \pm 1.9(8.8-16.8)$ & $13.6 \pm 0.9(12.5-15.6)$ & 0.372 \\
\hline Haemoglobin $(<12 \mathrm{~g} / \mathrm{dL})$ & $4(12.1)$ & $0(0.0)$ & 0.114 \\
\hline Haematocrit $(\%)$ & $40.6 \pm 5.1(31.3-51)$ & $40.2 \pm 2.1(36.1-44.3)$ & 0.644 \\
\hline MCV $(\mathrm{fl})$ & $82.4 \pm 7.7(59-98.6)$ & $83 \pm 3.8(71-91)$ & 0.728 \\
\hline RDW $(\%)$ & $14.4 \pm 2.2(11.7-19.6)$ & $14.3 \pm 1.2(12.4-17.8)$ & 0.577 \\
\hline MCH $(\mathrm{pg})$ & $27.2 \pm 3.2(16.3-33.1)$ & $27.8 \pm 2.5(20.9-33.3)$ & 0.520 \\
\hline Vitamin B12 $(\mathrm{pg} / \mathrm{mL})$ & $303.2 \pm 178.4(107-797)$ & $222.6 \pm 85.5(98-407)$ & 0.092 \\
\hline Folate $(\mathrm{ng} / \mathrm{mL})$ & $12.1 \pm 5(3.4-24)$ & $8.7 \pm 3.1(3.1-17.3)$ & 0.001 \\
\hline Iron $(\mu \mathrm{mol} / \mathrm{L})$ & $79.6 \pm 44.5(10.9-186)$ & $71.1 \pm 30.9(3-130)$ & 0.375 \\
\hline TIBC $(\mu \mathrm{mol} / \mathrm{L})$ & $329.2 \pm 55.9(248-461)$ & $355.6 \pm 32.5(254-412)$ & 0.022 \\
\hline Ferritin $(\mu \mathrm{g} / \mathrm{L})$ & $53 \pm 34.2(2.6-139)$ & $30.3 \pm 30.8(5.3-156.1)$ & $\mathbf{0 . 0 0 1}$ \\
\hline TIBC To & & & \\
\hline
\end{tabular}

TIBC: Total iron-binding capacity, DM: diabetes mellitus, MCV: mean corpuscular volume, RDW: red cell distribution width, MCH: mean corpuscular hemoglobin

Table 3. Correlation of metabolic parameters in diabetes mellitus type-1 patients with anaemia-haemogram parameters

\begin{tabular}{|l|l|l|l|l|}
\hline & & $\begin{array}{l}\text { Duration of } \\
\text { DM }\end{array}$ & $\begin{array}{l}\text { Insulin U/kg/ } \\
\text { day }\end{array}$ & HbA1c \\
\hline Haemoglobin & rho & -0.217 & 0.012 & 0.246 \\
\hline Haematocrit & $p$ & 0.224 & 0.947 & 0.168 \\
\hline MCV & rho & -0.233 & 0.001 & 0.304 \\
\hline & $p$ & 0.192 & 0.995 & 0.085 \\
\hline RDW & rho & -0.110 & 0.192 & 0.021 \\
\hline & $p$ & 0.544 & 0.285 & 0.907 \\
\hline MCH & rho & -0.017 & -0.185 & 0.075 \\
\hline Vitamin B12 & $p$ & 0.924 & 0.303 & 0.676 \\
\hline & rho & -0.103 & 0.204 & -0.049 \\
\hline Folate & $p$ & 0.567 & 0.254 & 0.786 \\
\hline & rho & 0.142 & 0.175 & 0.035 \\
\hline Iron & $p$ & 0.429 & 0.329 & 0.847 \\
\hline & rho & -0.047 & -0.042 & -0.345 \\
\hline TIBC & $p$ & 0.794 & 0.816 & 0.049 \\
\hline & rho & -0.124 & 0.204 & -0.118 \\
\hline Ferritin & $p$ & 0.491 & 0.254 & 0.512 \\
\hline & rho & 0.180 & -0.101 & -0.233 \\
\hline & $p$ & 0.317 & 0.576 & 0.191 \\
\hline & rho & -0.327 & -0.208 & 0.206 \\
\hline & $p$ & 0.063 & 0.247 & 0.250 \\
\hline
\end{tabular}

TIBC: Total iron-binding capacity, DM: diabetes mellitus, MCV: mean corpuscular volume, RDW: red cell distribution width, MCH: mean corpuscular hemoglobin, rho: Spearman's rank correlation coefficient

\section{Discussion}

To date, few studies have assessed the prevalence of anaemia among children with type-1 DM and its effects on metabolic control. In some studies, patients with type-2 diabetes and anaemia, usually accompanied by renal complications, were available $(6,7)$. In the paediatric population, disturbances of renal function are rare. Therefore, anaemia among children with type-1 DM and its causes are controversial.
We found that only 4/33 (12.1\%) patients had anaemia in the case group, which were caused by iron deficiency and there was no statistically significant difference between the groups $(p=0.114)$. Similarly, Akkermans et al. (1) found lower prevalence rates of anaemia among children with type-1 DM. Specifically, they performed a twocentre prospective observational study in which the iron statuses of 227 children with type-1 DM were investigated. Their results indicated that iron deficiency anaemia prevalence was 3.1\% and chronic disease prevalence was 3.7\%. The deprived iron status was observed in 113 (50\%) of the 227 children. In the study of Rusak et al. (9), none of the children with type-1 DM had anaemia. Although it is suggested that children with type-1 DM may be at a higher risk for anaemia, studies on this subject are rare. In an analysis of 200 Egyptian children with type-1 DM, anaemia was diagnosed in $37 \%$ of the patients and anaemia developed as a consequence of parasitic infestations and a lower socioeconomic situation (5).

In our patients, iron metabolism parameters and vitamin B12 levels were within the normal ranges, but the comparison of the case and control groups indicated that ferritin and folate concentration were higher and TIBC was lower in the case group. Normal vitamin B12 and iron concentrations in children with type-1 DM were also described by other authors (10). Normal iron status, B12 levels and high folic acid may be the result of regular controls and healthy nutrition. Higher ferritin and lower TIBC may be markers of inflammation (11). It is known that type-1 DM is an inflammatory disease. Rusak et al. (9) studied the markers of anaemia in children with type-1 DM and found significantly higher RDW, hepcidin which is a marker of inflammation, anaemia and vitamin B12 concentrations and lower TIBC.

In children with type-1 DM, knowledge about the impact of anaemia on $\mathrm{HbA} 1 \mathrm{c}$ levels is rare and the results are conflicting. In some studies, the iron statuses of children and their potential impact on $\mathrm{HbA1c}$ levels were studied. Results indicated that decreased iron levels might lead to increased HbA1c levels. (12-14). Tarim et al. (4) and Salah et al. (5) reported elevated $\mathrm{HbA} 1 \mathrm{c}$ levels in type1 DM patients with iron deficiency anaemia. They described a significant decrease in HbA1c levels after iron replacement therapy in patients with iron deficiency anaemia. In contrast with several previous studies, our results suggest that anaemia 
and haemogram parameters have no effect on $\mathrm{HbA1c}$ concentrations. A previously mentioned report from Akkerman et al. (1) also found that $\mathrm{HbA1c}$ levels were not associated with iron deficiency.

In this study, haemogram parameters, TIBC, serum iron and vitamin B12 and ferritin levels did not show a relationship with duration of diabetes, HbA1c, or daily insulin dosage. However, there was a significant negative correlation with $\mathrm{HbA} 1 \mathrm{c}$ and serum folate concentrations. It is considered that folate deficiency in children with type-1 DM might affect metabolic control. Therefore, additional studies to assess the relationship between folate concentration and $\mathrm{HbA} 1 \mathrm{c}$ are needed.

Our study had an advantage over previous studies because we evaluated anaemia-haemogram parameters and their association with metabolic parameters, including insulin treatment dose, duration of diabetes and HbA1c. However, our results were limited by a small sample size.

\section{Conclusion}

The present study confirms that metabolic control parameters are not associated with haemogram and anaemia parameters in children with type-1 DM. Nevertheless, additional studies with larger sample sizes are recommended.

\section{Ethics}

Ethics Committee Approval: The study protocol was approved by the Ethics Committee of Haseki Training and Research Hospital (protocol number: 79-02/05/2014) and the study was performed in accordance with the Declaration of Helsinki. Informed Consent: Informed consent forms were completed by all the participants.

Peer-review: Externally peer-reviewed

Authorship Contributions: Concept- S.A.; Design - S.A., M.E.; Data Collection or Processing - N.S.D.; Analysis or Interpretation - M.E.; Literature Search - N.S.D.; Writing- S.A., M.E.

Conflict of Interest: No conflict of interest was declared by the authors.

Financial Disclosure: The authors declared that this study received no financial support.

\section{References}

1. Akkermans MD, Mieke Houdijk ECA, Bakker B, Boers AC, van der Kaay DCM, de Vries MC, et al. Iron status and its association with HbA1c levels in Dutch children with diabetes mellitus type 1. Eur J Pediatr 2018; 177: 603-10.

2. Wojciak RW, Mojs E, Stanislawska-Kubiak M. The occurrence of iron-deficiency anemia in children with type 1 diabetes. J Investig Med 2014; 62: 865-7.

3. Gallager EJ, Le Roith D, Bloomgarden Z. Review of hemoglobin A1C in the management of diabetes. J Diabetes 2009;1: 9-17.

4. Tarim O, Küçükerdoğan A, Gunay U, Eralp O, Ercan I. Effects of iron deficiency anemia on hemoglobin A1c in type 1 diabetes mellitus. Pediatr Int 1999; 41: 357-62.

5. Salah N, El Hamid FA, Abdelghaffar S, El Sayem M. Prevalence and type of anaemia in young Egyptian patients with type 1 diabetes mellitus. East Mediterr Health J 2005; 11: 959-67.

6. Ito H, Takeuchi Y, Ishida H, Otawa A, Shibayama A, Antoku S, et al. Mild anemia is frequent and associated with micro- and macroangiopathies in patients with type 2 diabetes mellitus. J Diabetes Investig 2010; 1: 273-8.

7. Ezenwaka CE, Jones-LeCointe A, Nwagbara E, Seales D, Okali F. Anaemia and kidney dysfunction in Caribbean type 2 diabetic patients. Cardiovasc Diabetol 2008; 7: 25.

8. American Diabetes Association. Diagnosis and classification of diabetes mellitus. Diabetes Care 2014; (37 Suppl 1): S81-90.

9. Rusak E, Rotarska-Mizera A, Adamczyk P, Mazur B, Polanska J, Chobot A Markers of Anemia in Children with Type 1 Diabetes Journal of Diabetes Research. J Diabetes Res 2018; 2018: 5184354.

10. Forte G, Bocca B, Peruzzu A, Tolu F, Asara Y, Farace C, et al. Blood metals concentration in type 1 and type 2 diabetics. Biol Trace Elem Res 2013; 156 : 79-90.

11. Raj S, Rajan GV. Correlation between elevated serum ferritin and HbA1c in type 2 diabetes mellitus. Int J Res Med Sci 2013; 1: 12-5.

12. Ahmad J, Rafat D. HbA1c and iron deficiency: a review. Diabetes Metab Syndr 2013; 7: 118-22.

13. English E, Idris I, Smith G, Dhatariya K, Kilpatrick ES, John WG. The effect of anaemia and abnormalities of erythrocyte indices on $\mathrm{HbA} 1 \mathrm{c}$ analysis: a systematic review. Diabetologia 2015; 58: 1409-21.

14. Sinha N, Mishra TK, Singh T, Gupta N. Effect of iron deficiency anemia on hemoglobin A1clevels. Ann Lab Med 2012; 32: 17-22. 